\title{
Strategies for preventing the spread of fish and shellfish diseases
}

\author{
*Timothy W. Flegel ${ }^{1}$ and Daniel F. Fegan ${ }^{2}$ \\ 'Centex Shrimp, Chalerm Prakiat Building, Faculty of Science, Mahidol University, sctwf@mahidol.ac.th and 'Na- \\ tional Center for Genetic Engineering and Biotechnology, Ministry of Science, Technology and Environment Com- \\ pound, dfegan@usa.net, Rama6 Road Bangkok10400,Thailand
}

SUMMARY: As the size and intensity of aquaculture enterprises increase in this millennium, so will the scale for potential loss from disease. Economies dependent on them for export earnings will be vulnerable to disastrous epizootics that must be avoided by implementation of appropriate safeguards. These should be based on a scientific determination of disease transfer risks and be designed to have minimum impact on international trade. The risk assessment process outlined by the WTO SPS agreement exemplifies this approach. We will illustrate the issues on preventing the spread of fish and shellfish diseases based on our experience with two shrimp viruses (IHHNV and WSSV). The greatest risk for disease spread lies with careless movement of living animals for aquaculture. Other risks will also be reviewed. Ultimately, intensive aquaculture will move towards closed recycle systems based on domesticated and genetically improved stocks. The impetus for this will come mostly as a result of pressure from national trade requirements concerning human and veterinary health risks, and from consumer groups concerned about the environment and animal welfare.

\section{KEY WORDS: aquaculure, disease, risk, prevention}

\section{INTRODUCTION}

Capture fisheries have reached their limits and the shortfall in future fish and shellfish demand for an ever increasing world population must come from aquaculture ${ }^{1)}$. As the size and intensity of aquaculture enterprises increase, so will the scale for potential loss from disease. Economies dependent on aquaculture for export earnings will be vulnerable to disastrous epizootics such as the staggering lost production due to white spot syndrome virus (WSSV) in Asia since 19932) and in Latin America since 1999. It will be increasingly important to avoid disease outbreaks by implementation of "appropriate safeguards" based on scientific determination of disease transfer risks and designed to have a minimum impact on international trade. The risk assessment process outlined by the World Trade Organization Agreement on the Application of Sanitary and Phytosanitary Measures (SPS agreement) exemplifies this approach.

We contend that the greatest risk for spread of diseases lies by far with the careless, cross-boundary movement of living animals or fry destined directly for aquaculture facilities. There have been many examples of exotic species introductions according to the Food and Agricultural Organization statistics summarized in Table 1. This shows that about $65 \%$ of exotic species introductions have been intentional, and that $69 \%$ of these (39\% of the total) have been for aquaculture. The vast majority of introduced species $(82 \%)$ have been finfish (Table 2 ), followed distantly by mollusks ( $9 \%$ ) and crustaceans $(6 \%)$. All would have the potential to carry pathogens. In our view, the most ominous would be viral and parasitic diseases that would otherwise have very little chance of being introduced.

Table 1. Causes of aquatic species invasions. Source: http://www.fao.org/waicent/faoinfo/fishery/statist/fisoft/ dias/statisti.htm

\begin{tabular}{|l|r|r|}
\hline Cause of import & No. of records & $\%$ \\
\hline Known and intentional & 1386 & 39 \\
\hline Aquaculture & 299 & 8 \\
\hline Fisheries & 263 & 7 \\
\hline Ornamental & 104 & 3 \\
\hline Research & 272 & 8 \\
\hline Oher reasons & $\mathbf{2 3 2 4}$ & $\mathbf{6 5}$ \\
\hline Total intentional & & \\
\hline Known but unintentional & 283 & 8 \\
\hline Angling/sport & 139 & 4 \\
\hline Diffused from other countries & 267 & 8 \\
\hline Accidental & 14 & $>1$ \\
\hline Bait & $\mathbf{7 0 3}$ & $\mathbf{2 0}$ \\
\hline Total unintentional & $\mathbf{5 5 2}$ & $\mathbf{1 5}$ \\
\hline Unknown & & \\
\hline
\end{tabular}


Table 2. Species introductions by type. Source: http:// www.fao.org/waicent/faoinfo/fishery/statist/fisoft/dias/ statisti.htm

\begin{tabular}{|l|r|r|}
\hline Group of species & \# records & $\%$ \\
\hline Fishes & 2574 & 82 \\
\hline Molluscs & 294 & 9 \\
\hline Crustaceans & 191 & 6 \\
\hline Algae and plants & 35 & 1 \\
\hline Other invertebrates & 29 & 1 \\
\hline Other vertebrates & 18 & 1 \\
\hline
\end{tabular}

Because we are shrimp specialists, most of the examples given here will be for shrimp. However, the concepts and principles discussed could be equally applied to fish, mollusks and other aquatic species. We will focus on two shrimp viruses as recent examples of pathogens introduced with living shrimp for aquaculture, but other risks will also be reviewed. The strategy is to reduce these importation risks while also strengthening internal programs for direct disease control, including surveillance and (when appropriate) treatment, vaccination and confinement of outbreaks. In our opinion, intensive aquaculture operations will inexorably move towards closed recycle systems or otherwise bio-secure systems based on the cultivation of domesticated and genetically improved stocks. The impetus for this will come mostly as a result of pressure from international trade requirements concerning human health and import risks, and from consumer groups concerned about the environment and animal welfare.

\section{INFECTIOUS HYPODERMAL AND HEMATO- POIETIC NECROSIS VIRUS (IHHNV)}

IHHNV was first discovered in the blue shrimp Penaeus stylirostris and white shrimp $P$. vannamei in the Americas in the early $1980^{\prime} \mathrm{s}^{3,4)}$ where it is believed to have been introduced by importation of live experimental stocks of black tiger shrimp Penaeus monodon from Asia ${ }^{5}$. Work on this virus has been reviewed on several occasions ${ }^{6,7)}$. IHHNV has been reported in several species of wild and cultured penaeid shrimp throughout the world" , but causes acute epizootics and mass mortality only in $P$. stylirostris. By contrast, it causes reduced growth and deformities in $P$. vannamei. Shrimp that survive IHHNV epizootics may carry the virus for life and pass it on by vertical and horizontal transmission ${ }^{7}$. Infected adults seldom show signs of the disease or mortalities ${ }^{8}$. P. monodon appears to be relatively unaffected by IHHNV while Penaeus indicus and Penaeus merguiensis appear to be refractory to infection ${ }^{6,7,9)}$.
It is important to realize that IHHNV was unknown before it jumped from exotic $P$. monodon to American $P$ stylirostris and $P$. vannamei. We now know that IHHNV is endemic and prevalent in Asian P. monodon where it rarely harms its host. Indeed, highly sensitive polymerase chain reaction (PCR) assays may be required to detect its presence ${ }^{10}$. This is the type of scenario that poses the most serious disease threat to present and future aquaculture operations: i.e., a relatively innocuous (and possibly unknown) endemic pathogen (particularly viral) is moved together with a living aquatic animal over a large geographical distance to a new location where the local aquaculture species (or even local varieties of the import species) may be much more severely affected. Crustaceans may be particularly problematic because of their apparent propensity to have persistent, single to multiple viral infections without gross or even histological signs of disease ${ }^{(0)}$. As far as we know, the total lost production from retarded growth and mortality due to IHHNV has not been estimated, but it must be substantial when taken over the whole shrimp aquaculture industry in the Americas since the early 1980's. Some indication of its impact can however be gained from work carried out with stocks of shrimp bred specifically to be free of IHHNV infection. In an intensive system in $\mathrm{Ha}$ waii, removal of IHHNV related "runting" increased crop value by $162 \%$ over infected stock"1.

\section{WHITE SPOT SYNDROME VIRUS (WSSV)}

Although WSSV initially caused serious shrimp production losses in Asia only $y^{2}$, it must now be considered the single most serious shrimp pathogen worldwide. It was first reported from farmed Penaeus japonicus in Japan in $1993^{12 \cdot 16)}$ and called penaeid rod-shaped DNA virus (PRDV) or rod-shaped nuclear virus of P. japonicus (RV$P J)^{12,13,15,17,18)}$. Similar rod-shaped viruses from elsewhere in Asia were called by various names ${ }^{2}$ but Lightner ${ }^{7)}$ grouped them in a single white spot syndrome virus (WSSV) complex. WSSV is now considered to represent a new virus family ${ }^{19}$ tentatively called Whispoviridae or Nimaviridae ${ }^{20}$. Captured broodstock and postlarvae used to stock rearing ponds are known to carry WSSV, as are numerous other crustaceans and perhaps even aquatic insect larvae, but massive mortality usually occurs with juvenile shrimp in rearing ponds, probably precipitated by environmental factors ${ }^{10)}$.

In Thailand, outbreaks of WSSV in shrimp culture ponds initially occurred in $1994^{21,22)}$ and caused a peak estimated lost production of 70,000 metric tons in 1996. The total, cumulative lost production for all Asian countries since 1993 must now amount to several hundred 
thousand tons. However, losses were later reported from the USA ${ }^{23)}$, Central America and South America and molecular biological techniques have shown that WSSV from these outbreaks is identical or closely related to that in Asia ${ }^{22-28)}$. Thus, by 2001 the cumulative global loss to WSSV must be in the order of 1 million metric tons or more.

The WSSV outbreaks in Japan were the first widely reported, but they actually followed Chinese outbreaks and apparently resulted from the import of living post larvae from China directly to aquaculture facilities in Japan ${ }^{14)}$. No one knows how the virus spread throughout Asia after that, but the common practice of moving broodstock and postlarvae freely amongst countries was probably the most rapid and effective means of spread. Almost certainly WSSV was spread from Thailand to Malaysia and India in this manner. In addition, WSSV was not reported from the Philippines until $2000^{29}$, probably because of an effective Philippine government ban on importation of broodstock and postlarvae. Anecdotal evidence suggests that the Philippine outbreaks in the late 1990's originated from illegal import of postlarvae from China. As in Asia, a good part of WSSV spread in the Americas probably resulted from international transport of live shrimp for aquaculture ${ }^{30}$.

We find it curious that WSSV had not been reported from China prior to the catastrophic disease outbreaks in 1993, in spite of the fact that shrimp aquaculture had been practiced there for many years. The nature of the outbreaks was reminiscent of the initial IHHNV outbreaks for $P$. stylirostris in the Americas, suggesting that they may have originated from importation of a distant, exotic aquaculture species carrying a previously unknown pathogen. Although a possible link has never been investigated, it is interesting that red claw (Cherax quadricarinatus), an Australian freshwater crayfish, had been imported into China for aquaculture in the immediate period before the outbreaks. The possibility that it may have been the original source of WSSV in China should be investigated. Evidence from Ecuador may support this possibility. We have discovered and confirmed by in situ hybridization the presence of WSSV in archived slides and paraffin blocks of diseased $P$. vannamei from Eduador from 1996 (Flegel and Alday de Graindorge, unpublished). Thus, it was actually present three years before the widespread WSSV epizootics in 1999 and approximately two years after the importation of Australian red claw for aquaculture in 1994. In addition, 10 healthy red claw specimens from 3 Ecuadorian freshwater areas, remote from the sea, tested positive for WSSV by polymerase chain reaction (PCR) assay in 2000 (Alday de Graindorge, unpublished). Although WSSV can be lethal in experimental red claw infections ${ }^{31)}$, our field data from Ecuador suggest that it may carry the virus at low levels without gross signs of disease.

\section{OTHER SHRIMP VIRUSES}

Yellow-head virus was first reported from Thailand in $1990^{32}$, although the causative agent was not identified until two years later ${ }^{33.34}$. Viruses closely related to YHV have been reported from $P$. monodon in Australia ${ }^{35.36)}$, where they have been named gill associated virus (GAV) and lymphoid organ virus (LOV). YHV is a rod shaped, enveloped, positive sense, ssRNA virus, probably belonging to a new family allied to the Coronaviridae ${ }^{37,38}$. It is capable of infecting several penaeid species, including those from the western hemisphere ${ }^{23,34}$. It can also infect planktonic shrimp species that are common residents of shrimp ponds as grossly normal carriers (e.g. Palaemon styliferus and Acetes sp.).

YHV caused serious losses in Thai production in the early 1990's but has been overshadowed by WSSV since 1994. Although severe YHV outbreaks have declined in frequency since the early 1990's, they still do occur and cause significant production losses. In spite of this, the virus is has not spread as widely as WSSV, judging from the low frequency of reports from other countries in Asia and from the Americas ${ }^{23,40)}$.

Taura syndrome (TS) was first described as a shrimp disease in Ecuador in 1992 ${ }^{41)}$ and later found to be caused by a virus named Taura Syndrome virus or TSV ${ }^{42.433}$. It is a cytoplasmic, non-enveloped, icosahedral, positivesense ssRNA virus and tentatively classified as a picornavirus ${ }^{44,45}$. TSV was a serious cause of shrimp mortality for reared $P$, vannamei in the Americas where it spread principally through regional and international transfer of live postlarvae and broodstock. More recently, it was reported from $P$. vannamei reared in Taiwan after importation of live shrimp stocks from the Americas ${ }^{46}$. Although TSV infects a number of penaeid species ${ }^{7}$, it has caused serious commercial losses only for juvenile to adult stages of $P$. vannamei.

\section{RISK ASSESSMENT}

As with the international spread of disease for other aquaculture species, IHHNV, WSSV and other shrimp viruses appear to have spread mainly through the move- 
ment of infected broodstock and fry (postlarvae). However, other possible routes of disease introduction need to be considered. These include importation of green frozen shrimp, processed shrimp, shrimp head-meal, and crustaceans in released ballast water.

\section{Import of live animals}

Growing perception of environmental and disease threats has led to increased interest in uniform standards for importation of all living marine animals and plants. A Code of Practice Regarding Introductions of Non-indigenous Marine Organisms was proposed by the International Council for the Exploration of the Sea (ICES) in 1973. For introduction of animals already part of current commercial practice, the Code gave guidelines for reducing the risk of pathogen introduction ${ }^{47}$. For shrimp the Code would recommend that:

(a) An imported broodstock population should be established in an approved quarantine facility. The progeny, but not the original import, should be transplanted into the natural environment or farms only if no diseases or parasites became evident during the quarantine period. The quarantine period would provide opportunity for observation and its duration would be at least one complete life cycle, regardless of the stage at which the shrimp had been introduced.

(b) All effluents from quarantine facilities would be sterilized in an approved manner, killing all living organisms.

(c) If evidence of disease was obtained during the quarantine period, the introduced animals and their offspring would be destroyed immediately and the facility sterilized.

Given the experience with IHHNV in $P$. monodon, it would seem prudent to add to clause (a) the requirement that local species of shrimp, and especially economically important ones, be included as co-habitants in the quarantine phase. This would guard against the unintentional transfer of any well-tolerated, unknown pathogen from the exotic host to local species that might be more vulnerable and more seriously affected. Doing this would have avoided the release of IHHNV in the Americas, WSSV in Japan and TSV in Taiwan. However, to make the guidelines work, standard protocols for inspection, disease diagnosis, and certification of shipments of live marine animals are required and the infrastructure for this is not always in place. More than anything, increased awareness of the threats among aquaculture practitioners is needed.

In addition to the ICES code, signatories to the GATT and WTO are bound by the Agreement On The Application of Sanitary and Phytosanitary Measures (the "SPS Agreement"). The SPS Agreement applies to all sanitary and phytosanitary measures which may, directly or indirectly, affect international trade, including trade in live organisms. It permits sanitary and phytosanitary measures necessary to protect human, animal or plant life or health, but only if they are based on scientific principles. They cannot be maintained without sufficient scientific evidence, and must not arbitrarily or unjustifiably discriminate between members where identical or similar conditions prevail. In particular, it states that measures cannot be applied in a manner that would constitute a disguised restriction on international trade.

The risk of introducing exotic pathogens can be reduced significantly by using specific pathogen-free (SPF) stocks. However, in addition to possible deficiencies in SPF technology, other disease problems may develop from unknown pathogens in the imported populations. SPF stocks may also vary in the specific pathogens for which they are designated "free", so the excluded pathogens must be clearly identified.

Another approach with viral diseases is to develop resistant shrimp strains or to use shrimp species that are "specific pathogen resistant" (SPR), regardless of their pathogen status. However, "resistant" shrimp may sometimes carry the relevant virus as a persistent infection and be capable of introducing it to naïve populations. Even if a virus of the same name is already present in a native population, new strains may be introduced with SPR stocks and their prevalence might be maintained or increased. In addition, stress during farming can trigger increased viral replication in shrimp, resulting in disease outbreaks. There is also a danger that an exotic virus could mutate into a more pathogenic strain. This is particularly important for TSV and YHV, since RNA viruses are known to mutate and evolve rapidly ${ }^{48}$. Even with SPF or SPR shrimp, first importation should involve co-habitation tests with local species and varieties to guard against introduction of unknown pathogens.

Fortunately, excellent diagnostic probes are available for all of the major shrimp pathogens ${ }^{49}$ and they can be applied for screening broodstock and fry before importation and stocking. For example, PCR screening of shrimp 


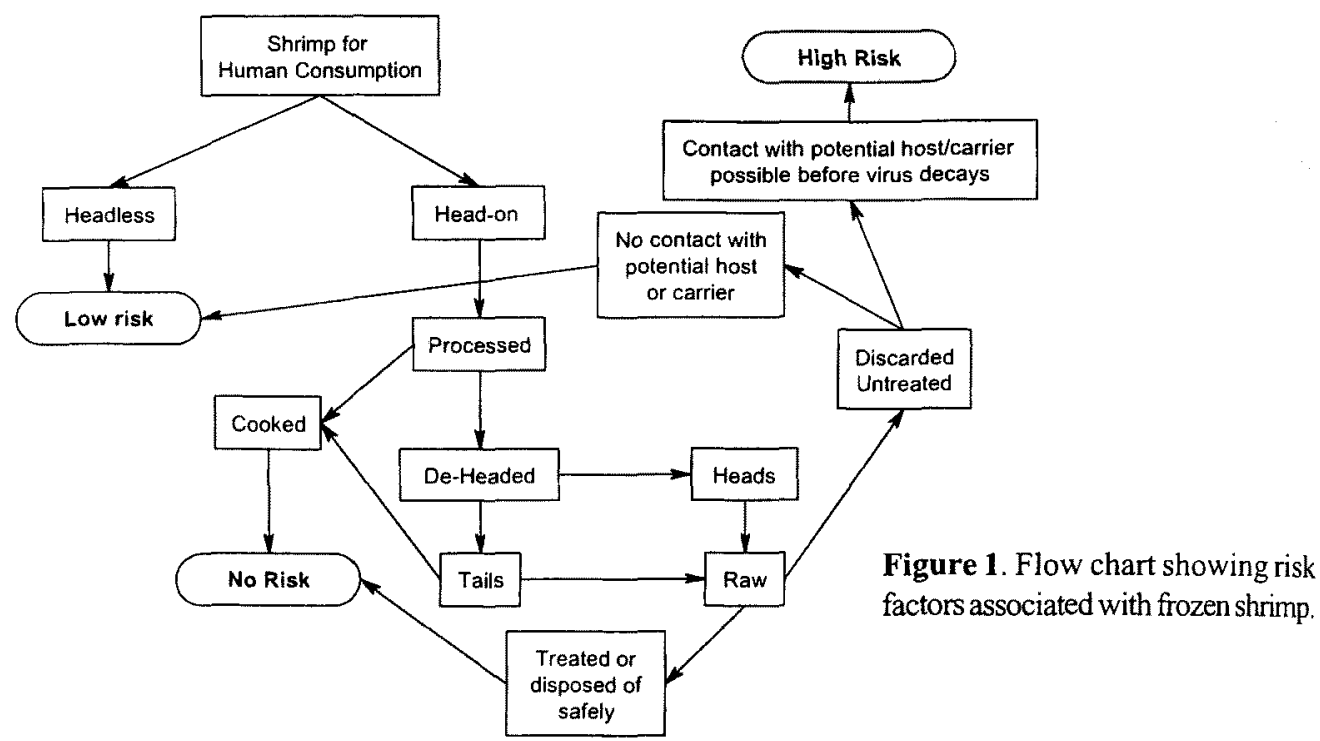

postlarvae before stocking is now a routine practice for many Asian shrimp farmers, and it has been credited with reducing the risk of WSSV outbreaks ${ }^{50,51)}$. As a corollary, the risk of introducing IHHNV, WSSV and other viruses with unscreened, living, captured animals or their fry from infected areas is extremely high.

\section{Import of processed shrimp}

Importation of cooked, dried and salted shrimp pose no threat of pathogen introduction, as the conditions used in their processing regime would inactivate the viruses.

\section{Import of green shrimp}

Green shrimp are fresh/frozen raw shrimp. Careful assessment shows that the possible risks from green shrimp vary greatly with product target use and the likelihood that viable viral particles present in frozen carcasses will reach a susceptible host. Pathogen viability can be affected by factors such as processing time, freezing and thawing after processing. The usage pattern and disease risks for various types of green shrimp are shown in Fig. 1 and discussed in the following paragraphs.

Before proceeding, however, we would like to caution against the use of PCR analysis to detect virus infection in commodity shrimp (i.e., processed or frozen shrimp) PCR is a very sensitive method for the detection of pathogens. However, it is based on detection of relatively small nucleic acid fragments and so can give positive results with non-viable viral particles or even degraded DNA (i.e., un-infectious material). Due to the high risk of dis- ease transfer associated with living stocks destined for aquaculture, it is generally accepted as a valid test for screening live animals (OIE, Diagnostic Manual for Aquatic Animal Diseases), and we can accept that some rejected animals will be assay positive but un-infectious. However, PCR assays and even bioassays to evaluate the disease status of frozen shrimp carcasses destined for human consumption is, in our view, inappropriate since the relative risk of disease transfer from this source is likely to be low, as described in the following paragraphs.

\section{Green shrimp for bait}

Green bait shrimp are generally inexpensive and small (under $10-15 \mathrm{~g}$ ) and may be a potential route for dissemination of shrimp pathogens. Meyers ${ }^{52}$ has suggested that the European strain of virulent viral haemorrhagic septicaemia virus (VHSV) arose through the habit of feeding frozen bait to hatchery fish, and laboratory experiments have shown that frozen, Asian shrimp from supermarkets can result in WSSV disease when thawed and fed directly to test shrimp in an aquarium ${ }^{30,53}$.

The use of green shrimp as commercial fishing bait or as a feed for live aquaculture stocks could allow viable viral particles to reach a susceptible host. Feeding them to hatchery stocks would be particularly dangerous, since it could contaminate fry destined for widespread stocking in culture ponds. Since bait shrimp are small and of low value, they are not usually farmed shrimp. On the other hand, emergency harvested shrimp from farms may be sold as bait if they are of small size. Since emergency harvests are frequently related to viral outbreaks, then 
bait shrimp that originate from shrimp aquaculture ponds may entail higher risk than those from natural sources. However, this does not mean that bait shrimp captured in the wild pose no risk. Indeed, it is known that natural infections of WSSV and YHV do occur in wild populations ${ }^{24,54,55}$ although the frequency is probably variable with season and source.

The risk of shrimp disease transfer via sport fishing bait is a hot issue of debate in Australia where recreational fishing is a popular sport. In our opinion, the risk from this is very low when one considers all of the necessary factors. For example, Australia bans the import of bait shrimp, so that most bait shrimp used is of local origin. This is almost always heads-on (H-ON) shrimp. However, it is possible that a small percentage of more expensive imported table shrimp or shrimp illegally labeled as bait shrimp might be used for fishing. Using data for 1998 Thai exports to Australia (Table 3), 320 tons of $\mathrm{H}$ ON frozen green shrimp were imported into Australia. If we assume all of this was used as bait, dividing this amongst the 92,000 recreational fishermen in the Northern Territories alone (not all of Australia) who spend a total of 2.2 million hours fishing annually (A survey of recreational fishing in the Northern Territory; http:// www.nt.gov.au/dpif/fisheries/recfish/fishfacts.shtml), would give a negligible amount of $1.6 \mathrm{mg}$ of bait per fisherman per fishing hour per year. This suggests a relatively low potential risk of transmission from this source. If this amount were divided amongst all Australian fishermen for a year it would result in an even lower risk of exposure.

Even if an infection was by chance successfully achieved by this route, we would have to consider that the infection would have to become established and that only a portion of the infected animals could potentially lead to permanent establishment of the pathogen in the local environment. Further transmission from the environment to aquaculture facilities would reduce the probability still further. Although many of the proportions given are guesses, a recent publication has shown that the infection coefficient from highly viremic whole shrimp in an aquarium is $0.6^{56)}$ (i.e., of every 100 exposures, only 60 result in infection). In spite of our belief that there is low risk from recreational fishing bait, we do however, support the Australian Quarantine Inspection Service (AQIS) recommendation (Prawn product import risk analysis: technical issues paper, Australian Quarantine and Inspection Service, Canberra) that it be further reduced by a ban on the import of green bait shrimp origi- nating from WSSV endemic areas. This belief is based on a consideration of the ease of implementation, the potential impact of the disease on Australian farmers, and equally importantly the relatively minor impact on international trade in this commodity.

It has also been recommended that the practice of feeding shrimp broodstock with green shrimp and other crustaceans be discontinued in Taiwan and in Thailand $d^{24.541}$ because of the risk of transferring WSSV and other viruses. This is true whether the feeds used are local or imported. Indeed, the practice of feeding raw crustaceans should be completely discontinued in shrimp aquaculture facilities given the potential risk of pathogen transfer.

Table 3. Shrimp exports from Thailand to Australia, 1997-1998.

\begin{tabular}{|c|c|c|c|c|}
\hline \multirow[t]{2}{*}{ Product Type } & \multicolumn{2}{|l|}{1997} & \multicolumn{2}{|l|}{1998} \\
\hline & Wt (Kg) & $\%$ & $\mathbf{W t}(\mathrm{Kg})$ & $\%$ \\
\hline Frozen Raw H-ON & 33,036 & 1.1 & 320,297 & 6.9 \\
\hline Frozen Raw H-SO & 5,511 & 0.2 & 13,800 & 0.3 \\
\hline Frozen Raw Peeled & 607,617 & 20.0 & 542,187 & 11.6 \\
\hline Sub-Total & 648,161 & 21.3 & 878,284 & 18.9 \\
\hline Frozen Cooked H-ON & 255,530 & 8.4 & 831,537 & $\overline{17.8}$ \\
\hline Frozen Cooked H-SO & - & - & 14,208 & 0.3 \\
\hline Frozen Cooked Peeled & $2,140,394$ & 70.3 & $2,937,285$ & 63.1 \\
\hline Sub-Total & $2,395,924$ & 78.7 & $3,783,030$ & $\overline{81.2}$ \\
\hline Total & $3,044,085$ & 100.0 & $4,661,314$ & $\overline{100.0}$ \\
\hline
\end{tabular}

Green shrimp for the food processing industry

There is a possibility that viable viral particles could reach a susceptible host from improperly handled waste of processing plants. Processing water could be a source of viable viral particles, depending on a number of complex factors, but certainly requiring a rather direct mixing with water containing shrimp or other susceptible crustaceans. However, in normal practice, processing water from peeling and heading operations is rather high in BOD and is not allowed to be discharged directly into open waters. After passing through treatment ponds and reaching quality standards acceptable for discharge, it is very doubtful that any viable virus particles would be present.

For solid wastes, Lightner $^{30)}$ has proposed that an outbreak of WSSV in Texas may have originated from a factory processing imported, Asian shrimp and discard- 
ing residues in an open dump from whence birds dropped infected carcass residues in nearby shrimp ponds. Although the suggestion remains unsubstantiated, frequent reference to this publication has given it the weight of fact in some forums and led to the argument that imported, exotic, green shrimp present a serious risk to aquaculture with native shrimp. We accept that improperly discarded solid wastes may entail greater risks of disease transfer than discharge water, and that both materials would present an extreme risk if introduced directly into receiving waters with susceptible crustacean hosts. However, determining the degree of risk from solid waste would also be complex and depend upon volume of material, viral loads, time in the dump before transfer, relative susceptibility of local species, virus viability, etc. As with bait shrimp, assessment of these risks and their inclusion in a full risk assessment would probably indicate a relatively low risk compared with more direct means of virus transfer. A simple solution to this problem would be to locate processing plants away from shrimp farming areas and to refrain from using open dumps. Because WSSV has many hosts ${ }^{10)}$, processing plants dealing with the fresh water prawn (Macrobrachium rosenbergii) $^{57)}$ and other crustaceans imported from WSSV infected areas should also regard these precautions.

Processing plants are generally very hygienic and use chlorinated water or other disinfectants in processing and cleaning. WSSV has been inactivated by exposure to sodium hypochlorite and povidone-iodine ${ }^{58.59}$. It is also inactivated by heating at $50^{\circ} \mathrm{C}$ for $20 \mathrm{~min}$, by drying at $30^{\circ} \mathrm{C}$ and by treatment with ethyl ether. In $12.5 \%$ sodium chloride solution the virus is inactivated in $24 \mathrm{~h}$ at $25^{\circ} \mathrm{C}$, although at high concentration it survives in sterile sea water at low temperature $\left(4^{\circ} \mathrm{C}\right)$ for up to 120 days. By contrast, water from outbreak ponds appears to be infectious in the open environment for not more than 4 days $^{54)}$.

Two practical and easily implemented measures can be recommended to reduce the risk of infection from processing plants to negligible levels. For exporting countries, it should be possible to introduce simple, rapid, and inexpensive procedures to prevent shrimp arising from WSSV outbreak ponds being used in export production lines. This would reduce the already low risk of transfer. These procedures could be quickly adopted by voluntary inclusion in existing HACCP routines. For importing countries, appropriate waste disposal regulations should be introduced for re-processors of imported shrimp, and if possible, they should not be located near shrimp aquaculture operations. As with bait shrimp, the cost associated with the impact of any disease and the relative ease of implementation of control measures would have to be taken into account. However, the volumes of material are much larger and this would also have to be considered on a disease by disease basis to establish a clear cost benefit.

\section{Green shrimp for direct human consumption}

We believe that the risk of viral transfer to shrimp aquaculture via shrimp destined for human consumption is very low whether the shrimp are whole, head-off or de-veined. Any perceivable risk can be easily eliminated by implementation of simple risk reduction procedures, such as those outlined in the previous section. Our contention is based on the fact that green shrimp have been traded globally in the order of one million metric tons per year without any proven link to the transfer of disease to aquaculture. For example, IHHNV is endemic and highly prevalent in Asian P. monodon, yet the virus did not cause difficulties in the Americas until imported with living stocks for aquaculture. In another example, Japan has a resident shrimp aquaculture industry for $P$. japonicus. It is also one of the world's biggest per capita importers of shrimp with a good portion of this being frozen shrimp from Southeast Asia. In addition to frozen shrimp, Japan also imports live $P$. japonicus and $P$. monodon. From 1991 to 1998 during which time YHV was continuously reported, Japan imported 360,000 metric tons of fresh and frozen shrimp from Thailand alone. Approximately 1,000 metric tons was imported as live shrimp directly to the restaurant trade. There have been no reports of YHV outbreaks in Japan, in spite of this very large quantity, the very small geographic area of Japan, the relative proximity of most food processing plants to the sea and the lack of any specific risk reduction measures. Similarly, the USA imported 326,000 tonnes of fresh and frozen shrimp from Thailand over the same period with no evidence of YHV transfer by this route. Even for WSSV, the "evidence" for transfer by this route remains highly circumstantial and, given the volume of shrimp treated annually, outbreaks of the disease have been negligible in importing countries. There have also been no reports of YHV or WSSV transfer from Thailand to Australia, although the volume of imported shrimp (22,000 metric tonnes 1994-1998) was less than $1 / 10$ of that to the USA and Japan.

Actual risks associated with the import of frozen shrimp for human consumption will depend upon the subsequent 
treatment of these products. Laboratory infection tests ${ }^{30,56 \text { ) }}$ demonstrate that transmission by this route is theoretically possibile but the likelihood of disease through this route needs to be assessed based on the actual risks and probabilities involved as shown in Fig. 1. It can be seen that there is little risk associated with standard importing and marketing practices and end-use (cooking at home, for example). Indeed, given normal household and restaurant practice, it is difficult to imagine a route for viral transfer that would present any significant level of probable risk. Other risks arising from improper disposal of processing waste or product diverted for bait have already been considered.

As an example of risk calculation, shrimp exports from Thailand to Australia for 1997 and 1998 are shown in Table 3 . In both years the majority of shrimp were imported as cooked product which carries no risk of transfer of WSSV or any other virus. Of the frozen raw shrimp, most is peeled or head-off product which has a limited risk. The highest potential risk, from frozen raw head-on product represented $1.1 \%$ and $6.9 \%$ of total imports in 1997 and 1998 respectively. The risk associated with these imports is represented in Fig. 2. Of the approximately $7 \%$ of shrimp which were imported as frozen raw head-on in 1998, most would probably have been subsequently cooked as either head-on or after deheading. The main risk would be with any infected, uncooked raw waste of which an unknown proportion may be disposed of in such a way as to bring it into contact with potential hosts during the time within which the vinus remains infective.

In summary, there has been no known disease transfer from household or restaurant shrimp to aquaculture ponds or wild populations and we believe there is no reason to restrict trade in these products. This is in agreement with the AQIS prawn risk study for Australia (Draft prawn risk analysis, Australian Quarantine Inspection Service, Canberra, 2000).

\section{Shrimp head meal and pelleted shrimp feed}

Shrimp heads discharged from processing plants are often used for the production of shrimp head meal, a common ingredient in pelleted shrimp feeds. Even though these animals might have been infected with WSSV/YHV, the time-temperature regime used during head meal processing and feed manufacture would be sufficient to inactivate the virus. For example, some studies on viral inactivation have been carried out and some of these have been published ${ }^{58-62)}$. A review of the head meal processing conditions and feed processing conditions revealed that

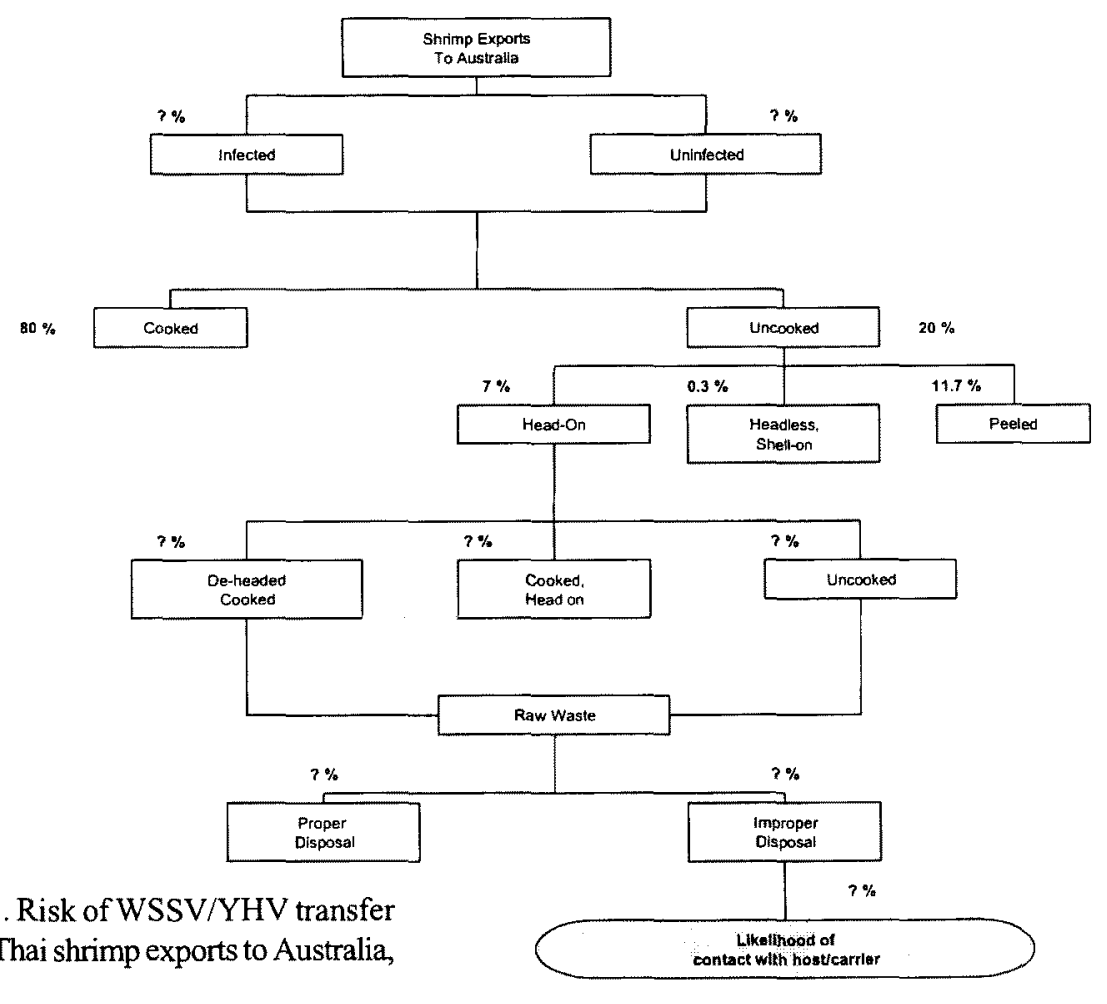

Figure 2. Risk of WSSV/YHV transfer through Thai shrimp exports to Australia, 1998 
the temperatures involved excluded the possibility of viral transfer by the feed route, and bioassay studies with WSSV in headmeal have confirmed this ${ }^{60-62)}$. As a result, we are completely confident that these viruses cannot be transferred via the feed and it is accepted that shrimp headmeal inclusion in shrimp feed presents no reasonable risk of disease transfer. No experience from here or elsewhere has given any indication that this conclusion is invalid for IHHNV or TSV either.

\section{Ballast water and fouling organisms}

Increased travel and trade are providing many more opportunities for the introduction of new diseases. Cargo ships contain huge ballast tanks that are routinely filled and emptied to maintain stability with a vessel holding up to $3,500 \mathrm{~m}^{3}$ of water. Together with the water, infected/carrier animals can be collected and discharged. Indeed, discharged ballast water and sediment has led to unplanned and unwanted introductions of non-native plants, animals and pathogens ${ }^{63}$. Fouling organisms on hulls and ropes have also been introduced. These routes of introduction are particularly worrisome in the case of WSSV for which over 50 crustacean carriers have been found ${ }^{(0)}$, some of which are very small and planktonic.

The Smithsonian Institute's invasion site (http:// invasions.si.edu/nmic. htm) shows that known invaders at Chesapeake Bay amount to 228 species with fish $21 \%$, mollusks $11 \%$ and crustaceans $9 \%$. The Australian Center for Research on Introduced Pests (CRIMP) gives data from Port Phillip Bay, Victoria ${ }^{64)}$ with an estimate of 300 400 exotic marine species already established in the bay and an estimate of 2-3 new exotic species being established each year. Just for one harbor, that would account for 14 to 21 newly established species, including perhaps 1 to 2 crustaceans (10\%) since the beginning of the WSSV epizootic in China. This does not account for those species that remain for a while but do not become established. The estimated numbers for released organisms are staggering. One can get some idea of the magnitude by using a spreadsheet for calculation of the theoretical of introductions from ballast water developed by Gollasch ${ }^{65}$. This spreadsheet is based on results of the first European ship sampling study on ballast water and tank sediments undertaken on nearly 200 vessels in German ports from 1992 to 1996 and relates the potential scale of introductions by the volume of traffic and type of shipping using the port. We used the spreadsheet to calculate the estimated number of living zooplankton specimens from foreign sources entering the water at Lamchabang port in Thailand in the year 2000. The result was approximately 100 to 1,900 specimens per sec- ond or 3.6 billion to 61 billion per year. This is only one port. Although there are several caveats in the use of this spreadsheet for calculation of ballast water introductions in different situations and in calculating the potential risk of disease introduction by this route, we believe it provides important information related to the possible scale of the problem associated with this previously little considered route of transmission. We believe that the risk of disease transfer by this route, although considerably lower than that from the import of live animals for aquaculture, may be greater than that from frozen products for human consumption due to the volume of ballast water and potential scale of introductions involved. The increasing size and speed of bulk carriers on international shipping routes makes survival of organisms in ballast water even more likely. Further spread of introduced organisms via coastal currents and domestic shipping may occur.

Given this risk, it is perhaps not surprising that WSSV first caused widespread outbreaks in Central America, including Panama, in early 1999. In April 1999, we assisted in PCR testing of freshly captured broodstock shrimp at the Smithsonian Institute in Panama. The results showed $9 / 60$ positive for WSSV (unpublished), suggesting that the virus had been established in the local marine environment for a considerable period before the outbreaks. One possibility is that it was introduced there by Asian vessels approaching the Panama canal although this has been disputed on the basis that ballast discharge is not permitted in the canal zone. On the other hand, this does not discount the possibility of disease transmission through organisms fouling the hulls of vessels.

The International Maritime Organisation (IMO) has established some voluntary guidelines on ballast water handling although some of the suggested solutions are impractical from an operational viewpoint, being either prohibitively expensive or physically impossible. One option, the use of chemicals, would require approval by government agencies and could pose a threat to the ship crew and environment. However, judicious use of shortlived insecticides might be effective in eliminating arthropod carriers of WSSV and other diseases, reducing the probability of their transmission.

The IMO regards mid-ocean ballast water exchange (MOE) where the depth exceeds $2,000 \mathrm{~m}$ as the most effective method of ballast treatment. The idea is that species picked up in harbours are unlikely to survive when pumped out into the open ocean and that organ- 
isms taken from open oceans would be generally less likely to survive when released in coastal waters. However, this method has some limitations as the amount of ballast water that can be exchanged varies with ship design and sea conditions and ships moving along the coast would not be able to follow these guidelines. In addition, a recent study by Botnen ${ }^{66}$ indicates that organisms including fish and crustaceans survive in ballast water tanks for long distances and times and that MOE changes the fauna assemblage in the ballast water, but that some organisms either remain in the tanks during water exchange or are brought back in along with the new water. Thus, for various reasons, even if MOE is implemented, ballast water would still be a possible means to spread diseases.

Whatever method is adopted, introduction and acceptance of ballast water exchange methods can only buy time until better technologies and ship designs are available to reduce the risk of exotic species transfers. The Marine Environment Protection Committee is presently working on an annex to MARPOL (the IMO convention for the prevention of pollution from ships) to make the application of the guidelines mandatory. We believe that there is a real risk of introducing WSSV and other virus diseases through the discharge of ballast water in coastal areas but the degree of this risk is difficult to estimate since it depends upon a number of variable factors. Estimations of risk associated with ballast water would have to be done on a case-by-case basis. However, mandatory ballast water exchange rules established for vessels moving between specific regions may help to limit the problem.

\section{CONCLUSIONS}

The highest risk of introducing pathogens is through the import of live animals (broodstock and fry) from infected areas. Intentional movement of live animals should be restricted and carried out following ICES regulations. This should also be applied to SPF stocks and in particular to SPR stocks of shrimp, since we already know these are likely to be infected with the viruses they resist. In addition, local initiatives can be taken such as the Asia Regional Guidelines for Responsible Movement of Live Aquatic Animals which are being formulated through a project of the Network of Aquaculture Centers in Asia Pacific (NACA), the United Nations Food and Agriculture Organisation (FAO) and the Office Internationale des Epizooties (OIE). These guidelines will form a basis for responsible and safe movement of live aquatic animals.
The degree of risk of introducing pathogens through frozen food depends more on the possibility of viable viral particles contacting a new host, than on the viral load of the carcasses themselves. Therefore, frozen products used for bait and feeding live stocks, would be classified as high risk as they would be released into the environment or fed directly to susceptible hosts. Products imported for the processing industry, would represent a risk only when the waste was not properly disposed of and where there existed the possibility of mechanical transport of a sufficient dose of viable pathogen to susceptible hosts within the time during which the pathogen remained infective. In our opinion, the possibility of this happening would represent a low risk. For similar reasons, we believe that frozen product imported for direct human consumption represents an even lower risk. Processed shrimp and shrimp head meal would pose no threat as temperature and drying procedures would inactivate pathogens. The release of ballast waters into coastal areas and the presence of fouling organisms on ship hulls poses a threat difficult to assess, and needs further investigation, but to us seems to present a much bigger threat for disease transfer than that from imported shrimp for human consumption due to the volumes of water and number of organisms involved. Although ballast water exchange as recommend by the IMO, is the most practical method so far suggested to reduce the disease transfer risk, we believe that the risks associated with ballast water and fouling organisms deserve further study.

\section{REFERENCES}

1. De Silva SS. A global perspective of aquaculture in the new mellinnium. In: Anon., ed. Book of Synopses. Conference on aquaculture in the third mllennium. Bangkok: Network of Aquaculture Centres in Asia-Pacific and Food and Aquaculture Organization of the United Nations, 2000: 51-100.

2. Flegel TW, Alday-Sanz V. The crisis in Asian shrimp aquaculture: current status and future needs. $J$. Appl. lcthyol. 1998; 14:269-273.

3. Lightner DV, Redman RM, Bell TA. Infectious hypodermal and hematopoietic necrosis, a newly recognized virus disease of penaeid shrimp. $J$. Invertebr. Pathol. 1983; 42:6270.

4. Bell TA, Lightner DV. IHHN virus: Infectivity and pathogenicity studies in Penaeus stylirostris and Penaeus vannamei. Aquaculture 1984; 38:185-194.

5. Lightner DV, Redman RM. Hosts, geographic range and diagnostic procedures for the penaeid virus diseases of concern to shrimp culturists in the Americas. In: DeLoach P, Dugherty WJ, Davidson MA, eds. Frontiers of shrimp research. Amsterdam, Netherlands: Elsevier, 1991: 173-196.

6. Lightner DV. Diseases of cultured penaeid shrimp. In McVey, JP eds. CRC handbook of mariculture, 2 ed. Boca Raton, 
FL: CRC Press, 1993: 393-486.

7. Lightner DV. A handbook of pathology and diagnostic procedures for diseases of penaeid shrimp. Baton Rouge, LA: World Aquaculture Society, 1996.

8. Kalagayan G, Godin D, Kanna R, Hagino G, Sweeney J, Wyban J, Brock J. IHHN virus as an etiological factor in runt-deformity syndrome of juvenile Penaeus vannamei cultured in Hawaii. $J$. World Aquacul. Soc. 1991; 22:235243.

9. Brock JA, Main K. A guide to the common problems and diseases of cultured Penaeus vannamei. Baton Rouge, LA: World Aquaculture Society, 1994.

10. Flegel TW. The shrimp response to viral pathogens. In: Browdy CL, Jory DE, eds. The new wave. Proceedings of the special session on sustainable shrimp aquaculture, World Aquaculture 2001, Orlando. Boca Raton: World Aquaculture Society, 2001: 190-214.

11. Wyban JA, Swingle IS, Sweeney JN, Pruder GD. Development and performance of high health shrimp using specific pathogen free (SPF) broodstock Penaeus vannamei. In: Wyban JA, ed. Proceedings of the special session on shrimp farming. Baton Rouge, IA: World Aquaculture Soc., 1992: 254-260.

12. Inouye $\mathrm{K}$, Miwa $\mathrm{S}$, Oseko $\mathrm{N}$, Nakano $\mathrm{H}$, Kimura $\mathrm{T}$, Momoyama K, Hiraoka M. Mass mortalities of cultured kuruma shrimp Penaeus japonicus in Japan in 1993: Electron microscopic evidence of the causative virus. Fish $\mathrm{Pa}$ thology 1994; 29:149-158.

13. Inouye $\mathrm{K}$, Yamano $\mathrm{K}$, Ikeda $\mathrm{N}$, Kimura $\mathrm{T}$, Nakano $\mathrm{H}$, Momoyama K, Kobayashi J, Miyajima S. The penaeid rod-shaped DNA virus (PRDV), which causes penaeid acute viremia (PAV). Fish Pathology 1996; 31:39-45.

14. Nakano H, Koube H, Umezawa S, Momoyama K, Hiraoka $\mathrm{M}$, Inouye $\mathrm{K}$, Oseko N. Mass mortalities of cultured kuruma shrimp, Penaeus japonicus, in Japan in 1993: Epizootiological survey and infection trails. Fish Pathology 1994; 29:135-139.

15. Momoyama K, Hiraoka M, Inouye K, Kimura T, Nakano H. Diagnostic techniques of the rod-shaped nuclear virus infection in the kuruma shrimp, Penaeus japonicus. Fish Pathology 1995; 30:263-269.

16. Momoyama K, Hiraoka M, Nakano $H$, Koube $H$, Inouye $K$, Oseko N. Mass mortalities of cultured kuruma shrimp, Penaeus japonicus, in Japan in 1993: Histopathological study. Fish Pathology 1994; 29:141-148.

17. Takahashi $\mathrm{Y}$, Itami T, Kondo M, Maeda M, Fujii R, Tomanaga S, Supamattaya K, Boonyaratpalin S. Electron microscope evidence of bacilliform virus infection in kuruma shrimp (Penaeus japonicus). Fish Pathology 1994; 29:121-125.

18. Kimura T, Yamano K, Nakano H, Momoyama K, Hiraoka $\mathrm{M}$, Inouye $\mathrm{K}$. Detection of penaeid rod-shaped DNA virus (PRDV) by PCR. Fish Pathology 1996; 31:93-98.

19. Tsai MF, Yu HT, Tzeng HF, Leu JH, Chou CM, Huang CJ, Wang CH, Lin JY, Kou GH, Lo CF. Identification and characterization of a shrimp white spot syndrome virus (WSSV) gene that encodes a novel chimeric polypeptide of cellular-type thymidine kinase and thymidylate kinase. Virology 2000; 277:100-110.

20. van Hulten MC, Witteveldt J, Peters S, Kloosterboer N,
Tarchini R, Fiers M, Sandbrink H, Lankhorst RK, Vlak JM. The white spot syndrome virus DNA genome sequence. Virology 2001; 286:7-22.

21. Wongteerasupaya C, Vickers JE, Sriurairatana S, Nash GL, Akarajamorn A, Bonsaeng V, Panyim S, Tassanakajon A, Withyachumnamkul B, Flegel TW, . A non-occluded, systemic baculovirus that occurs in the cells of ectodermal and mesodermal origin and causes high mortality in the black tiger prawn, Penaeus monodon. Dis.Aquat. Org. 1995; $21: 69-77$.

22. Wongteerasupaya $C$, Wongwisansri S, Boonsaeng $V$, Panyim S, Pratanpipat P, Nash GL, Withyachumnamkul B, Flegel TW. DNA fragment of Penaeus monodom baculovirus PmNOBII gives positive in situ hybridization with viral infections in six penaeid shrimp species. Aquaculture 1996; 143:23-32.

23. Loh PC, Cesar E, Nadala Ir. B, Tapay LM, Lu Y. Recent developments in immunologically-based and cell culture protocols for the specific detection of shrimp viral pathogens. In: Flegel TW, ed. Advances in Shrimp Biotechnology. Bangkok: National Center for Genetic Engineering and Biotechnology, 1998: 255-259.

24. Lo CF, Ho CH, Peng SE, Chen $\mathrm{CH}$, Hsu $\mathrm{HC}$, Chiu $\mathrm{YL}$, Chang CF, Liu KF, Su MS, Wang $\mathrm{CH}$, Kou GH. White spot syndrome baculovirus (WSBV) detected in cultured and captured shrimp, crabs and other arthropods. Dis. Aquat. Org. 1996; 27:215-225.

25. Lo CF, Hsu HC, Tsai MF, Ho CH, Peng SE, Kou GH, Lightner DV. Specific genomic DNA fragment analysis of different geographical clinical samples of shrimp white spot syndrome virus. Dis. Aquat. Org. 1999; 35:175-185.

26. Takahashi $Y$, Itami T, Maeda M, Suzuki N, Kasornchandra J, Supamattaya K, Khongpradit R, Boonyaratpalin S, Kondo M, Kawai K, Kusuda R, Hirono I, Aoki T. Polymerase chain reaction (PCR) amplification of bacilliform virus (RV-PS) DNA in Penaeus japonicus Bate and systemic ectodermal and mesodermal baculovirus (SEMBV) DNA in Penaeus monodon Fabricius. J. Fish Dis. 1996; 19:399-403.

27. Wang CS, Tsai YJ, Kou GH, Chen SN. Detection of white spot disease virus infection in wild-caught greasy back shrimp, Metapenaeus ensis (de Haan) in Taiwan. Fish Pathology 1997; 32:35-41.

28. Wang CH, Lo CF, Leu JH, Chou CH, Yeh PY, Chou HY, Tung MC, Chang CF, Su MS, Kou GH. Purification and genomic analysis of baculovirus associated with white spot syndrome (WSBV) of Penaeus monodon. Dis. Aquat. Org. 1995; 23:239-242.

29. Magbanua FO, Natividad KT, Migo VP, Alfafara CG, de la Pena FO, Miranda RO, Albaladejo JD, Nadala EC, Loh PC, Mahilum-Tapay L. White spot syndrome virus (WSSV) in cultured Penaeus monodon in the Philippines. Dis. Aquat. Org. 2000; 42:77-82.

30. Lightner DV, Redman RM, Poulos BT, Nunan LM, Mari JL, Hasson KW. Risk of spread of penaeid shrimp viruses in the Americas by the international movement of live and frozen shrimp. Rev. Sci. Tech. Off. Int. Epiz. 1997; 16:146-60.

31. Shi Z, Huang C, Zhang J, Chen D, Bonami JR. White spot syndrome virus (WSSV) experimental infection of the 
freshwater crayfish, Cherax quadricarinatus. J. Fish Dis. $2000 ; 23: 285-288$.

32. Limsuwan C. Handbook for cultivation of black tiger prawns. 222 Tansetakit Building, Wipawadee-Rangsit Road, Ladyaw, Chatujak, Bangkok: Tansetakit Co. Ltd., 1991.

33. Boonyaratpalin S, Supamattaya K, Kasornchandra J, Direkbusaracom S, Ekpanithanpong U, Chantanachooklin C. Non-occluded baculo-like virus, the causative agent of yellow head disease in the black tiger shrimp (Penaeus monodon). Fish Pathology 1993; 28:103-109.

34. Chantanachookin C, Boonyaratanapalin S, Kasornchandra J, Direkbusarakom S, Ekpanithanpong U, Supamataya K, Siurairatana S, Flegel TW. Histology and ultrastructure reveal a new granulosis-like virus in Penaeus monodon affected by "yellow-head" disease. Dis. Aquat. Org. 1993; 17:145-157.

35. Spann KM, Vickers JE, Lester RJG. Lymphoid organ virus of Penaeus monodon from Australia. Dis. Aquat. Org. 1995; 23:127-134.

36. Spann KM, Cowley JA, Walker PJ, Lester RJG. A yellowhead-like virus from Penaeus monodon cultured in Australia. Dis. Aquat. Org. 1998; 31:169-179.

37. Cowley JA, Dimmock CM, Wongteerasupaya C, Boonsaeng V, Panyim S, Walker PJ. Yellow head virus from Thailand and gill-associated virus from Australia are closely related but distinct prawn viruses. Dis. Aquat. Org. 1999; 36(2):153-7.

38. Cowley JA, Dimmock CM, Spann KM, Walker PJ. Gillassociated virus of Penaeus monodon prawns: an invertebrate virus with ORF $1 \mathrm{a}$ and $\mathrm{ORF} 1 \mathrm{~b}$ genes related to arteriand coronaviruses. J. Gen. Virol. 2000; 81:1473-1484.

39. Lu Y, Tapay LM, Brock JA, Loh PC. Infection of the yellow head baculovirus (YBV) in two species of penaeid shrimp, Penaeus stylirostris (Stimpson) and Penaeus vannamei (Boone). J. Fish Dis. 1994; 17:649-656.

40. Mohan CV, Shankar KM, Kulkarni S, Sudha PM. Histopathology of cultured shrimp showing gross signs of yellow head syndrome and white spot syndrome during 1994 Indian epizootics. Dis. Aquat. Org. 1998; 34:9-12.

41. Jimenez R. Sindrome de Taura (Resumen). Acuacultura del Ecuador 1992:1-16.

42. Hasson KW, Lightner DV, Poulos BT, Redman RM, White BL, Brock JA, Bonami JR. Taura Syndrome in Penaeus vannamei: Demonstration of a viral etiology. Dis. Aquat. Org. 1995; 23:115-126.

43. Lightner DV, Redman RM, Hasson KW, Pantoja CR. Taura syndrome in Penaeus vannamei (Crustacea: Decapoda): gross signs, histopathology and ultrastructure. Dis. Aquat. Org. 1995; 21:53-59.

44. Bonami JR, Hasson KW, Mari J, Poulos BT, Lightner DV. Taura syndrome of marine penaeid shrimp: characterization of the viral agent. J. Gen. Virol. 1997; 78:313-319.

45. Brock JA, Gose RB, Lightner DV, Hasson KW. Recent developments and an overview of Taura Syndrome of farmed shrimp in the Americas. In: Flegel TW, MacRae I, eds. Diseases in Asian Aquaculture III, Manila, Philippines: Fish Health Section, Asian Fisheries Society, 1997: 275283.

46. Tu C, Huang HT, Chuang SH, Hsu JP, Kuo ST, Li NJ, Hsu TL, Li MC, Lin SY. Taura syndrome in Pacific white shrimp Penaeus vannamei cultured in Taiwan. Dis. Aquat. Org. 1999; 38:159-161.

47. Sindermann CJ. Strategies for reducing risks from introductions of aquatic organisms: a marine perspective. Bull. Amer. Fish. Soc. 1986; 11(2):10-15.

48. Steinhauer DA, Holland JJ. Rapid evolution of RNA viruses. Ann. Rev. Microbiol. 1987; 41:409-433.

49. Lightner DV, Redman RM. Shrimp diseases and current diagnostic methods. Aquaculture 1998; 164:201-220.

50. Chanratchakool P, Limsuwan C. Application of PCR and formalin treatment to prevent white spot disease in shrimp. In: Flegel TW, ed. Advances in Shrimp Biotechnology. Bangkok: National Center for Genetic Engineering and Biotechnology, 1998: 287-289.

51. Withyachumnarnkul B. Results from black tiger shrimp Penaeus monodon culture ponds stocked with postlarvae PCR-positive or -negative for white-spot syndrome virus (WSSV). Dis. Aquat. Org. 1999; 39:21-27.

52. Meyers TR, Short S, Lipson K, Batts WN, Winton JR, Wilcock J, Brown E. Association of viral haemorrhagic septicaemia virus with epizootic haemorrhages of the skin in Pacific herring Clupea harengus pallasi from Prince William Sound and Kodiak Island, Alaska, USA. Dis. Aquat. Org. 1994; 19:27-37.

53. Nunan LM, Poulos BT, Lightner DV. The detection of white spot syndrome virus WSSV and yellow head virus YHV in imported commodity shrimp. Aquaculture 1998; 160;1930.

54. Flegel TW, Boonyaratpalin S, Withyachumnamkul B. Current status of research on yellow-head virus and whitespot virus in Thailand. In: Flegel TW, MacRae I, eds. Diseases in Asian Aquaculture III. Manila: Fish Health Section, Asian Fisheries Soc, 1997: 285-296.

55. Maeda M, Itami T, Furumoto A, Hennig O, Imamura T, Kondo M, Hirono I, Aoki T, Takahashi Y. Detection of penaeid rod-shaped DNA virus (PRDV) in wild-caught shrimp and other crustaceans. Fish Pathology 1998; 33:373-380.

56. Soto MA, Shervette VR, Lotz JM. Transmission of white spot syndrome virus (WSSV) to Litopenaeus vannamei from infected cephalothorax, abdomen, or whole shrimp cadaver. Dis Aquat Organ 2001; 45:81-7.

57. Peng SE, Lo CF, Ho CH, Chang CF, Kou GH. Detection of white spot baculovirus (WSBV) in giant freshwater prawn, Macrobrachium rosenbergii, using polymerase chain reaction. Aquaculture 1998; 164:253-262.

58. Chang P-S, Chen L-J, Wang Y-C. The effect of ultraviolet irradiation, heat, $\mathrm{pH}$, ozone, salinity and chemical disinfectants on the infectivity of white spot syndrome baculovirus. Aquaculture 1998; 166:1-17

59. Maeda M, Kasomchandra J, Itami I, Suzuki N, Hennig O, Kondo M, Albaladejo JD, Takahashi Y. Effect of various treatments on white spot syndrome virus (WSSV) from Penaeus japonicus (Japan) and P. monodon (Thailand). Fish Pathol. 1998; 33:381-387.

60. Stevens WF, Cheypratub P, Haiqing S, Lertsutthiwong P, How NC, Chandrkrachang $S$. Alternatives in shrimp biowaste processing. In: Flegel TW, ed. Advances in shrimp biotechnology. Bangkok: National Center for Genetic Engineering and Biotechnology, 1998. 
61. Pongmaneerat J, Kasornchandra J, Boonyaratpalin S, Boonyaratpalin M. Effect of dietary shrimp head meal infected with systemic ectodermal and mesodermal baculovirus (SEMBV) on SEMBV infection in black tiger shrimp (Penaeus monodon). In: Anon., ed. Proceedings of the Annual Shrimp Biotechnology Seminar. Bangkok: National Center of Genetic Engineering and Biotechnology, 1997: 83-90.

62. Posomboon W. Processing effect on quality of dried shrimp. MSc thesis: Asian Institute of Technology, 1998.

63. Munday BL, Clark A, Hine M, Lester R, Whittington RJ. An epidemiological review of possible introductions of fish diseases, northern Pacific seastar and Japanese kelp through ship's ballast water. Canberra: Australian Government Publishing Service, 1994.
64. Hewitt CL, Campbell ML, Thresher RE, Martin RB. Marine biological invasions of Port Phillip Bay, Victoria: CSIRO, 1999.

65. Gollasch S. Adjustable calculation form to quantify the amount of ballast water transported in ballast tanks and discharged annually. http://members.aol.com/sgollasch/ sgollasch/index.htm.

66. Botnen H. Cruise summary report Pusan Senator, Kaosiung, Taiwan to Hamburg, Germany, May 19 to June 14, 1999: EU Concerted Action: Testing monitoring systems for risk assessment of harmful introductions by ships to European waters, 1999: http:/software.dnv.com/marmil/ ballastsampling/OGW3_CA9_Taiwan_99.htm. 